Pak. j. sci. ind. res. Ser. B: biol. sci. 2018 61B(2) 84-88

\title{
Optimisation of Production Condition of Alkaline Protease Using Indigenous Bacillus subtilis from Agricultural Soil
}

\author{
Barkat Ali Solangi ${ }^{a *}$, Hafiz Rub Nawaz ${ }^{a}$, Uzma Nadeem ${ }^{a}$, Beena Zehra ${ }^{a}$ and Agha Asad Noorb \\ ${ }^{a}$ PCSIR, Leather Research Centre, D-102, South Avenue, SITE, Karachi, Pakistan \\ ${ }^{b}$ Department of Microbiology, University of Sindh, Jamshoro, Pakistan
}

(received August 6, 2015; revised May 20, 2016; accepted August 15, 2016)

\begin{abstract}
In this study, proteases have been isolated from agricultural soil samples and then cultured by shake flask method. The growth of the Bacillus subtilis has been confirmed by microbiological test on the agar plate and skim milk agar in rough, raised and irregular colonies. The yield of the alkaline protease has been optimised by varying the main factors i.e., nitrogen source (peptone, yeast extract, beef extract, casein, ammonium carbonate and urea), carbon source (sucrose, fructose, mannose, lactose, glucose, maltose and starch), incubation period $(12,24,36,48,72,84$ and $96 \mathrm{~h})$, temperature $(35,40,45,50,55$, and $60{ }^{\circ} \mathrm{C}$ ) and salts (potassium sulphate, magnesium sulphate, calcium sulphate and manganese sulphate). The results revealed that the maximum enzyme production was obtained using casein and minimum activity was obtained using urea as a nitrogen source. Similarly, other factors have shown significant effect on the activity of the enzyme.
\end{abstract}

Keywords: proteases, agricultural soil, shake flask method, optimisation

\section{Introduction}

Microbial protease enzymes are widely utilized in most of the industries (Degering et al., 2010; Ramnani et al., 2005), such as in the detergent, food, pharmaceutical, leather, in peptide synthesis (Horikoshii, 1999), etc. They have a very large and complex group of enzymes with different properties of substrate specificity, active sites and catalytic mechanism, $\mathrm{pH}$, temperature and stability profiles. Proteases have also extensive application in a range of processes due to an advantage of the unique physical and catalytic properties of individual proteolytic enzyme types (Pant et al., 2015; Ward, 1991).

Microorganisms are an attractive source of protease as they can be cultured in large quantities in a relatively short time by established fermentation methods producing an abundant, regular supply of the desired product. Besides, they can be genetically manipulated to generate new enzymes with altered properties that are desirable for their various applications (Gupta et al., 2002; Rao et al., 1998). Bacterial proteases are mostly extracellular, easily produced in larger amounts, thermostable and active at wider $\mathrm{pH}$ range. These properties make the bacterial proteases most suitable for wider industrial applications. Alkaline proteases from bacterial origin are the most important industrial enzymes, which

*Author for correspondence; E-mail: 1rcpcsir@gmail.com contribute about $60 \%$ of the total world enzyme market (Outtrup and Boyce, 1990; Kalisz, 1988; Ward, 1985). These proteases produced by Bacillus pseudofirmus, Cohnella thermotolerans and Bacillus odysseyi are of great importance in detergent industry due to their high thermo and $\mathrm{pH}$ stability (Borsosi et al., 2005). This vast diversity of proteases, in contrast to the specificity of their action has attracted worldwide attention in attempt to exploit their physiological and biotechnological applications (Rao et al., 1998). The production of extracellular alkaline protease by Bacillus subtilis RSKK96 has been studied with solid state fermentation (Akcan and Uyar, 2011). In the recent years, protease has been produced by Bacillus licheniformis cells mobilized on the chitosan, corn cob and corn tassle and production conditions have been optimised (Maghsoodi et al., 2013). Another study describes the production of protease by Bacillus cereus strain and Bacillus cohnii and characterized the enzymatic properties (Lakshmi et al., 2014; Tekin et al., 2012). Thus, it is needed to search for proteases with significant properties from different sources, and the optimisation of conditions (such as temperature, $\mathrm{pH}$ and additives). Therefore, in this study the main objective was to explore the indigenous resources of protease producing bacteria, Bacillus subitilis and to determine the optimum conditions of protease production by varying nitrogen source, carbon source, incubation time, temperature, $\mathrm{pH}$ and salts. 


\section{Materials and Methods}

All chemicals used in this study were analytical grade purchased from Merck and BDH. Shaking Incubator and oven were from BINDER, GmbH, variable speed micro centrifuge was from Centurion Scientific Ltd.

Isolation of bacteria. Twenty five soil samples were collected in polythene bags from four different places of Karachi such as; Korangi industrial area, SITE area, Bin Qasim industrial area and agriculture soil of Memon Goth, where mainly protease were expected as shown in Table 1. A serial dilution $\left(10^{2}-10^{6}\right)$ of soil samples in sterile double distilled water was prepared and poured into separate $0.5 \mathrm{~mL}$ of the culture in petri plates and $15 \mathrm{~mL}$ of the melted nutrient agar at $40-50{ }^{\circ} \mathrm{C}$. The plates were mixed thoroughly by gentle rotations and left for solidification. The culture plates were incubated at $37{ }^{\circ} \mathrm{C}$ for $24 \mathrm{~h}$ and next day number of cells per $\mathrm{mL}$ of soil suspended samples were obtained by multiplying the final dilution with numbers of colonies. The selected colonies were used for further study.

Screening for best protease producing strain on medium. The isolates were screened for best protease producing strain by plate assay using protease specific medium containing skim milk, potassium dihydrogen phosphate, glucose, peptone, gelatin and agar-agar, at pH 7.2.

Production of protease. The culture positive for alkaline protease was grown by $100 \mathrm{~mL}$ of synthetic medium containing $(\mathrm{g} / \mathrm{L})$ nutrient broth with glucose $(5 \mathrm{~g})$, peptone $(7.5 \mathrm{~g}), \mathrm{NaCl}(5 \mathrm{~g}), \mathrm{FeSO}_{4} .7 \mathrm{H}_{2} \mathrm{O}(0.1 \mathrm{~g})$, $\mathrm{MgSO}_{4} .7 \mathrm{H}_{2} \mathrm{O}(5 \mathrm{~g})$ with the $\mathrm{pH} 10.0$. The medium was incubated for $48 \mathrm{~h}$ in shaker incubator $(120 \mathrm{rpm})$ at $37^{\circ} \mathrm{C}$. The fermented broth was filtered and the filtrate was centrifuged at $10,000 \mathrm{rpm}$ for $10 \mathrm{~min}$ at $4{ }^{\circ} \mathrm{C}$ to extract the crude extracellular protease.

Determination of protease activity by well diffusion method. Agar $1 \%$ was prepared using $1 \%(\mathrm{w} / \mathrm{v})$ casein, $1.5 \%$ skimmed milk, and $1 \%$ gelatin and poured in petri dishes. The plates were solidified for $30 \mathrm{~min}$ and holes of $3 \mathrm{~mm}$ diameter were punched. A crude culture supernatant from Bacillus subtilis was filled into the holes. These plates were incubated at $37{ }^{\circ} \mathrm{C}$ for $24 \mathrm{~h}$. After $24 \mathrm{~h}$ of incubation the protease activity was measured by zone.

Determination of the effect of nitrogen sources on alkaline protease production. Alkaline protease production was carried out in mediums 1 to 6 separately along with various nitrogen sources by replacing only peptone with other nitrogen sources like yeast extract, beef extract, casein, ammonium carbonate and urea, respectively. Each nitrogen source was used at $1 \%(\mathrm{w} / \mathrm{v})$ concentration, respectively.

Determination of the effect of carbon sources on alkaline protease production. Different carbon sources were used in this study such as sucrose, fructose, mannose, lactose, glucose, maltose and starch, to replace the carbon source available in the media. $0.5 \%(\mathrm{w} / \mathrm{v})$ concentration of different carbon source were used.

Determination of the effects of incubation time, temperature and salt concentration on protease production. The effect of incubation time on protease production was studied by changing incubation duration, such as 12, 24, 36, 48, 60, 72, 84 and $96 \mathrm{~h}$.

The effect of temperature on protease production was studied by maintaining various temperatures like 35 , $40,45,50,55$ and $60{ }^{\circ} \mathrm{C}$. Incubation time was for $48 \mathrm{~h}$ in shaking incubator with $120 \mathrm{rpm}$. After that, the protease enzyme activity was measured.

The role of salts on alkaline protease production was analysed by the addition of salts like potassium sulphate, magnesium sulphate, calcium sulphate and manganese sulphate added at $0.1 \mathrm{mg} / 100 \mathrm{~mL}$ to the medium.

\section{Results and Discussion}

The main sources of the protease enzymes isolation are usually animals (e.g. calf stomach), plants (e.g. pineapple, papaya), and microbes (e.g. Bacillus spp., Pseudomonas spp.) (Shafe et al., 2005; Rao et al., 1998), etc. Bacterial proteases are mostly extracellular, easily produced, thermostable and active at wider $\mathrm{pH}$ range. Therefore, Bacillus was selected to produce protease in this study. The soil samples were collected from different areas of Karachi and subjected to isolation of Bacillus subtilis as given in Table 1. The highest abundance of alkaline producing isolates of Bacillus subtilis were found in the agriculture soil sample collected from Memon Goth, Karachi whereas no isolates were found in the sample collected from Bin Qasim industrial area, Karachi. These isolates were characterized by their alkaline $\mathrm{pH}$ (8-12), with optimal temperature between $35^{\circ} \mathrm{C}$ and $60^{\circ} \mathrm{C}$. The growth of $B$. subtilis was confirmed by microbiological test on the nutrient agar plate and skim milk agar. The colonies on the nutrient agar plates were rough, raised, and irregular with rough margins, while 
on the skim milk agar, the colonies were glossy, smooth with rounded margins and clear zone of proteolysis. Bacillus was derived alkaline proteases and stable at elevated temperatures and $\mathrm{pH}$, but majority of them were incompatible with detergent matrices as reported earlier by Deng et al. (2010).

Proteases are differing in properties such as substrate specificity, active site and catalytic mechanism, $\mathrm{pH}$ and temperature and stability profiles. Studies relating to such properties are essential for the successful application of these enzymes in their respective industry (Sumantha et al., 2005). Among the organic nitrogen sources peptone, yeast extract, beef extract, casein, ammonium carbonate and urea had significant effect on protease production $560 \mathrm{U} / \mathrm{mL}, 535 \mathrm{U} / \mathrm{mL}, 590 \mathrm{U} / \mathrm{mL}, 650 \mathrm{U} / \mathrm{mL}$, $468 \mathrm{U} / \mathrm{mL}, 421 \mathrm{U} / \mathrm{mL}$, respectively. It was observed that the alkaline protease production was good in all cases but maximum enzyme production was obtained using casein and minimum was obtained using urea as nitrogen source as shown in Table 2, and agreed with results of Haddar et al. (2009). The amount of protease produced from microorganisms depends on the nature of strains and the composition of the growth medium (Nadeem et al., 2007; 2006). Actually, protease are produced at exponential phase of bacterial growth which is associated with the sporulation of $B$. subtilis (Elliot and May, 1968), whereas casein is a source of amino acids that enhances the foam formation to remove spores and cellular debris from the culture.

The effect of change of carbon source was determined by measuring enzyme activity. Different sources of carbon such as sucrose, fructose, mannose, lactose, maltose, and starch were used and replaced with the glucose as a carbon source in growth media. Results showed that the enzyme activity was highest in the glucose as compared to other carbon sources at $24 \mathrm{~h}$ and $48 \mathrm{~h}$ of incubation. Sucrose and fructose also showed high protease activity at $24 \mathrm{~h}$, but extremely reduced by $48 \mathrm{~h}$ of incubation as shown in Table 3 . This observation also supports the earlier reports which suggested that sources of carbon affected production of enzymes by bacteria (Juhasz et al., 2003). At $72 \mathrm{~h}$ incubation due to the prolonged incubation time perhaps led to auto digestion of proteases and proteolytic attack by other proteases (Horikoshii et al., 2006). Incubation time plays a substantial role in maximizing bacterial growth and protease production. Results in Table 4 showed that the enzyme activity was different at different incubation periods. It was maximum at $72 \mathrm{~h}$, while
Table 1. Sample collection and isolation of bacterial cells $/ \mathrm{mL}$

\begin{tabular}{llll}
\hline \hline Area of collection & $\begin{array}{l}\text { No. of } \\
\text { samples }\end{array}$ & $\begin{array}{l}\text { No. of } \\
\text { isolates }\end{array}$ & $\begin{array}{l}\text { No. of } \\
\text { cells } / \mathrm{mL}\end{array}$ \\
\hline Korangi industrial area & 5 & 4 & 38000 \\
Site area & 8 & 3 & 33000 \\
$\begin{array}{l}\text { Bin Qasim industrial area } \\
\text { Agriculture soil }\end{array}$ & 4 & 0 & 00 \\
(Memon Goth) Karachi & 8 & 1 & 43000 \\
\hline \hline
\end{tabular}

Table 2. Effect of nitrogen sources on protease enzyme activity

\begin{tabular}{lll}
\hline \hline Bacterial specie & Nitrogen sources & $\begin{array}{l}\text { Enzyme activity } \\
(\mathrm{U} / \mathrm{mL})\end{array}$ \\
\hline Bacillus subtilis & Peptone & $560 \pm 2.87$ \\
& Yeast extract & $535 \pm 2.11$ \\
& Beef extract & $590 \pm 2.33$ \\
& Casein & $650 \pm 3.20$ \\
& Ammonium carbonate & $468 \pm 2.35$ \\
& Urea & $421 \pm 3.34$ \\
\hline \hline
\end{tabular}

Table 3. Effect of carbon source on the protease enzyme activity

\begin{tabular}{lll}
\hline \hline Bacterial specie & Carbon source & $\begin{array}{l}\text { Enzyme activity } \\
(\mathrm{U} / \mathrm{mL})\end{array}$ \\
\hline Bacillus subtilis & Sucrose & $620 \pm 2.50$ \\
& Fructose & $580 \pm 2.73$ \\
& Mannose & $320 \pm 1.57$ \\
& Lactose & $292 \pm 1.75$ \\
& Glucose & $670 \pm 3.20$ \\
& Maltose & $340 \pm 2.33$ \\
& Starch & $280 \pm 2.15$ \\
\hline
\end{tabular}

Table 4. Effect of incubation periods on protease enzyme activity

\begin{tabular}{lll}
\hline \hline Bacterial specie & $\begin{array}{l}\text { Incubation period } \\
\text { (h) }\end{array}$ & $\begin{array}{l}\text { Enzyme activity } \\
(\mathrm{U} / \mathrm{mL})\end{array}$ \\
\hline Bacillus subtlis & 12 & $232 \pm 1.53$ \\
& 24 & $290 \pm 1.73$ \\
& 36 & $455 \pm 1.57$ \\
& 48 & $538 \pm 1.66$ \\
& 72 & $623 \pm 2.20$ \\
& 84 & $559 \pm 2.31$ \\
& 96 & $520 \pm 2.44$ \\
\hline
\end{tabular}


lowest at $12 \mathrm{~h}$. Temperature is also one of the most critical parameters that has to be controlled in bioprocessing (Chi et al., 2007). Therefore, the effect was optimised at different temperatures. The enzyme activity was highest at $45^{\circ} \mathrm{C}$ and lowest at $60^{\circ} \mathrm{C}$ (Table 5).

An increase in the protease activity was also observed in the presence of $\mathrm{Mg}^{+2}$ as shown in Table 6. It was also studied earlier that the metal ions such as; $\mathrm{Ca}^{+2}, \mathrm{Mg}^{+2}$ and $\mathrm{Mn}^{+2}$ increase the enzyme stabilization which results in the increase in enzyme activity and thermal stability of alkaline proteases at higher temperature (Kumar, 2002). Further, biochemical characterisation and application of enzyme is in progress.

Table 5. Effect of temperature on protease enzyme activity

\begin{tabular}{lll}
\hline \hline Bacteria specie & $\begin{array}{l}\text { Temperature } \\
\left({ }^{\circ} \mathrm{C}\right)\end{array}$ & $\begin{array}{l}\text { Enzyme activity } \\
(\mathrm{U} / \mathrm{mL})\end{array}$ \\
\hline Bacillus subtilis & 35 & $356 \pm 2.66$ \\
& 40 & $545 \pm 1.57$ \\
& 45 & $635 \pm 2.20$ \\
& 50 & $510 \pm 1.66$ \\
& 55 & $412 \pm 1.25$ \\
& 60 & $210 \pm 2.11$ \\
\hline \hline
\end{tabular}

Table 6. Effect of salts on protease enzyme activity

\begin{tabular}{lll}
\hline \hline Bacteria specie & Salts & $\begin{array}{l}\text { Enzyme activity } \\
(\mathrm{U} / \mathrm{mL})\end{array}$ \\
\hline Bacillus subtilis & Potassium sulphate & $432 \pm 2.77$ \\
& Magnesium sulphate & $620 \pm 3.55$ \\
& Calcium sulphate & $300 \pm 3.66$ \\
& Manganese sulphate & $358 \pm 2.25$ \\
\hline \hline
\end{tabular}

\section{Conclusion}

Bacillus subtilis is a good source for the production of protease enzymes which have many uses in industries. It is concluded in this study that the optimisation of protease production from Bacillus subtilis had led for better resource and appropriate factors such as; the agricultural soil was found a better source of microorganisms, casein as a best nitrogen source, glucose as a best carbon source, $48 \mathrm{~h}$ as best incubation period and $45{ }^{\circ} \mathrm{C}$ as a best temperature for Bacillus subtilis growth.

\section{References}

Ackan, N., Uyar, F. 2011. Production of extracellular alkaline protease from Bacillus subtilis RSKK96 with solid state fermentation. EurAsian Journal of Bio Sciences, 5: 64-72.

Borsosi, A.K., Micsinai, A., Rusznyak, A., Vladar, P., Kovacs, G., Toth, E.M., Marialigeti, K. 2005. Diversity of alkaliphilic and alkali tolerant bacteria cultivated from decomposing reed rhizomes in Hungarian Soda Lake. Microbiological Ecology, 50: 9-18.

Chi, Z., Ma, C., Wang, P., Li, H.F. 2007. Optimization of medium and cultivation conditions for alkaline protease production by the marine yeast Auerobasidium pullalans. Bioresource Technology, 98: 534538.

Degering, C., Eggert, T., Puls, M., Bongaerts, T., Evers, S., Maurer, K.-H., Jaeger, K.-E. 2010. Optimization of protease secretion in Bacillus subtilis and Bacillus licheniformis by screening of homologous signal peptides. Applied Environmental Microbiology, 76: 6370-6376.

Deng, A.H., Wu, J., Zhang,Y., Zhang, G.Q., Wen, T.Y. 2010. Purification and characterization of a surfactant- stable high-alkaline protease from Bacillus sp. B001. Bioresource Technology, 101: 7100-7106.

Elliot, W.H., May, B.K. 1968. Characterization of extracellular protease formation by Bacillus subtilis and its control by amino acids repression. Biochemical Biophysics, 157: 607-615.

Gupta, R., Beg, Q.K., Lorenz, P. 2002. Bacterial alkaline proteases: molecular approaches and industrial applications. Applied Microbiology and Biotechnology, 59: 15-32.

Haddar, A., Bougatef, A., Agrebi, R., Sellami-Kamoun, A., Nasri, M. 2009. A novel surfactant-stable alkaline serine-protease from anewly isolated Bacillus mojavensis A21. Purification and characterization. Process Biochemistry, 44: 29-35.

Horikoshii, K., Diúrak, M., Kojima, M., Kanai, M., Inoue, A. 2006. Isolation and characterization of a feather-degrading enzyme from Bacillus pseudofirmus FA30-01. Extremophiles, 10: 229235.

Horikoshi, K. 1999. Alkaliphiles: Some application of their products for biotechnology. Microbiology and Molecular Biology Reviews, 63: 735-750.

Juhasz, T., Kozma, K., Szengyel, Z., Réczey, K. 2003. 
Production of beta-glucosidase in mixed culture of Aspergillus niger BKMF 1305 and Trichoderma reesei RUT C30. Food Technology and Biotechnology, 41: 49-53.

Kalisz, H.M. 1988. Microbial proteinases. In: Advances in Biochemical Engineering/Biotechnology, Fiechter, A. (ed.), vol. 36, pp. 1-65, Springer, Berlin, Germany.

Kumar, C.G. 2002. Purification and characterization of a thermostable alkaline protease from alkalophilic Bacillus pumilus. Letters in Applied Microbiology, 34: 13-17.

Lakshmi, B.K.M., Ratna, S.P.V., Devi, K.A., Hemalatha, K.P.J. 2014. Screening, optimization of production and partial characterization of alkaline protease from haloalkaliphilic Bacillus sp. International Journal of Research in Engineering and Technology, 3: 435-443.

Maghsoodi, V., Kazemi, A., Nahid, P., Soheila, Y., Sabzevari, M.A. 2013. Alkaline protease production by immobilized cells using $B$. licheniformis. Scientia Iranica C, 20: 607-610.

Nadeem, M., Qazi, J.I., Baig, S.J., Syed, Q.A. 2007. Studies on commercially important alkalineprotease from Bacillus licheniformis $\mathrm{N}-2$ isolated from decaying organic soil. Turkish Journal of Biochemistry, 32: 171-177.

Nadeem, M., Baig, S.J., Syed, Q.A., Qazi, J.I. 2006. Microbial production of alkaline proteases by locally isolated Bacillus subtilis PCSIR-5. Pakistan Journal of Zoology, 38: 109-114.

Outtrup, H., Boyce, C.O.L. 1990. Microbial proteases and biotechnology. In: Microbial Enzymes and Biotechnology, W. M. Fogarty and C. T. Kelly (eds.), pp. 227-254, Elsevier Science, New York, USA.
Pant, G., Prakash, A., Pavani, J.V.P., Bera, S., Deviram, G.V.N.S., Kumar, A., Panchpuri, M., Prasuna, R.G. 2015. Production, optimization and partial purification of protease from Bacillus subtilis. Journal of Taibah University for Science, 9: 50-55.

Ramnani, P., Kumar, S.S., Gupta, R. 2005. Concomitant production and downstream processing of alkaline protease and biosurfactant from $B$. licheniformis RG1: bioformulation as detergent additive. Process Biochemistry, 4: 3352-3359.

Rao, M.B., Tanksale, A.M., Ghatge, M.S., Deshpande, V.V. 1998. Molecular and biotechnological aspects of microbial proteases. Microbiology and Molecular Biology Reviews, 62: 597-635.

Shafee, N., Aris, S.N., Rahman, R.Z.A., Basri, M., Salleh, A.B. 2005. Optimization of environmental and nutritional conditions for the production of alkaline protease by a newly isolated bacterium Bacillus cereus strain 146. Journal of Applied Sciences Research, 1: 1-8.

Sumantha, A., Sandhya, C., Szakacs, G., Soccol, C.R., Pandey, A. 2005. Production and partial purification of a neutral metalloprotease by fungal mixed substrate fermentation. Food Technology and Biotechnology, 43: 313-319.

Tekin, N., Cihan, A.C., Takac, Z.S., Tuzan, C.Y., Tunc, K., Cokmus, C. 2012. Alkaline protease production of Bacillus cohnii APT5. Turkish Journal of Biology, 36: 430-440.

Ward, O.P. 1991. Enzyme Bioprocessing Applications. In: Bioprocessing, pp. 151-170, Open University Press, Buckingham, UK.

Ward, O.P. 1985. Proteolytic enzymes. In: Comprehensive Biotechnology, M. Moo-Young (ed.), vol. 3, pp. 789-818, Pergamon, Oxford, UK. 